\title{
Studi Estimasi Beban Puncak Hari Libur Nasional Sistem Interkoneksi Sulselbar Menggunakan Jaringan Syaraf Tiruan Propagasi Balik
}

\author{
Makmur Saini ${ }^{1}$, A.M. Shiddiq Yunus ${ }^{2, *}$, Firdaus ${ }^{3}$ \\ 1,2 Jurusan Teknik Mesin, Politeknik Negeri Ujung Pandang, Makassar 90245, Indonesia \\ ${ }^{3}$ PLN Wilayah Abon \\ *shiddiq@poliupg.ac.id
}

\begin{abstract}
The development of population from time to time is increased and the need for electricity consumption is also increased. Simultaneously increasing the need for electric power requires the provider of electricity supply in this case PT. PLN (Persero) should deliver power effectively to consumers. To maximize the distribution of electricity to the consumer, a load planning is required. This load planning is conducted to find out how much amount of power is required by consumer. The purpose of this research is to investigate the need of power load of interconnection system of South Sulawesi and to investigate the accuracy of load planning using Artificial Neural Network (ANN) backpropagation.
\end{abstract}

Keywords: Load Planning, ANN, Bacpropagation.

\begin{abstract}
Abstrak: Perkembangan masyarakat dari waktu ke waktu semakin bertambah dan kebutuhan akan konsumsi tenaga listrik akan ikut meningkat. Peningkatan kebutuhan tenaga listrik mengharuskan penyedia pasokan listrik dalam hal ini PT. PLN (Persero) dapat menyalurkan tenaga listrik dengan efektif ke konsumen. Untuk memaksimalkan penyaluran tenaga listrik ke konsumen, maka dibutuhkan suatu perencanaan beban. Perencanaan beban ini dilakukan untuk mengetahui seberapa besar kebutuhan daya listrik ke konsumen. Tujuan dari penelitian ini adalah untuk mengetahui kebutuhan beban sistem interkoneksi Sulselbar dan mengetahui akurasi perencanaan beban dengan menggunakan Jaringan Syaraf Tiruan (JST) propagasi balik.
\end{abstract}

Kata Kunci: perencanaan beban, JST, propagasi balik.

\section{PENDAHULUAN}

Pemenuhan kebutuhan energi listrik mempunyai kedudukan yang penting dalam pembangunan nasional pada umumnya dan sebagai salah satu pendorong kegiatan ekonomi pada khususnya dalam rangka mewujudkan masyarakat adil dan makmur. Oleh karena itu, penyediaan tenaga listrik harus menjadi prioritas dalam pembangunan dan dalam prosesnya harus dikembangkan dengan prinsipprinsip efektifitas dan efisiensi.

Kebutuhan akan tenaga listtrik di suatu wilayah terus meningkat dari waktu ke waktu sejalan dengan meningkatnya kegiatan ekonomi dan kesejahteraan masyarakat di wilayah tersebut. Peningkatan kebutuhan tenaga listrik mengharuskan penyedia pasokan listrik dalam hal ini PT. PLN (Persero) dapat menyalurkan tenaga listrik dengan efektif ke konsumen. Jika terjadi gangguan pasokan tenaga listrik ke konsumen mengakibatkan rutinitas masyarakat akan terganggu. Oleh karena itu pasokan tenaga listrik ke konsumen harus tetap terjaga dan merupakan hal yang sangat penting.

Besarnya total daya yang dibangkitkan oleh pembangkit harus menyesuaikan dengan kebutuhan daya yang dibutuhkan konsumen. Untuk mengetahui seberapa besar kebutuhan daya yang perlu disalurkan ke konsumen, maka dari pihak penyalur dalam hal ini PT.PLN (Persero) perlu melakukan perencanaan yang matang dengan menggunakan metode perencanaan beban atau peramalan beban.

Peramalan adalah suatu kegiatan /usaha untuk memprediksi kondisi di masa yang akan datang dan merupakan salah satu cara untuk membantu dalam hal perencanaan pembangkitan maupun pemyaluran energi listrik. Peramalan beban dapat terbagi menjadi menjadi tiga kategori yaitu 
peramalan beban jangka pendek (short term load forecasting), peramalan beban jangka menengah (medium term load forecasting), dan peramalan beban jangka panjang (long term forecasting).

Dalam penelitian ini, metode jaringan syaraf tiruan propagasi balik (backpropagation) yang akan digunakan untuk meramal beban puncak tenaga listrik. Peramalan dilakukan untuk menghitung beban puncak di hari-hari libur nasional. Data yang digunakan dalam penelitian ini adalah data yang ada pada sistem ketenagalistrikan Sulselbar.

\section{A) Data}

Data merupakan kumpulan fakta yang diketahui atas berbagai hal kejadian nyata atau berdasarkan pengamatan. Data dapat digunakan sebagai dasar untuk penarikan suatu kesimpulan atau informasi dengan pengolahan yang sesuai [1].

Data dapat dikelompokkan menjadi beberapa jenis, yaitu:

1. Berdasarkan Sifatnya.

a. Data Kualitatif, merupakan data berdasarkan mutu atau pernyataan yang tidak disajikan dalam bentuk angka.

b. Data Kuantitatif, merupakan data yang disajikan dalam bentuk angka.

2. Berdasarkan Sumbernya.

a. Data Internal, merupakan data yang diperoleh dari dalam suatu instansi dan menggambarkan kondisi suatu instansi tersebut.

b. Data Eksternal, merupakan data yang diperoleh dari luar suatu instansi dan menggambarkan kondisi suatu hal di luar instansi yang memiliki data tersebut.

3. Berdasarkan Cara Memperolehnya.

a. Data Primer, merupakan data yang diperoleh secara langsung melalui hasil pengamatan dan diolah sendiri oleh pihak yang menggunakan data tersebut.

b. Data Sekunder, merupakan data yang diperoleh secara tidak langsung melalui hasil pengamatan dan diolah oleh pihak lain.

4. Berdasarkan Waktu Pengumpulannya.

a. Data Cross Section, merupakan data yang dikumpulkan pada satu waktu tertentu.

b. Data Time Series, merupakan data yang dikumpulkan dari waktu ke waktu pada rentang waktu tertentu.

\section{B) Klasifikasi Beban}

c. Data Panel, merupakan data gabungan antara data cross section dan time series.

Secara umum beban yang dilayani oleh sistem distribusi listrik ini dibagi dalam beberapa sektor yaitu sektor perumahan, sektor industri, sektor komersial, dan sektor usaha. Masing-masing sektor beban tersebut mempunyai karakteristik-karakteristik yang berbeda, sebab hal ini berkaitan dengan pola konsumsi energi pada masing-masing konsumen di sektor tersebut.

Berdasarkan jenis konsumen energi listrik, ragam beban dapat diklasifikasikan sebagai berikut [2]:

1. Beban rumah tangga, pada umumnya beban rumah tangga berupa lampu untuk penerangan, alat rumah tangga, seperti kipas angin, pemanas air, lemari es, penyejuk udara, mixer, oven, motor pompa air dan sebagainya. Beban rumah tangga biasanya memuncak pada malam hari.

2. Beban komersial, pada umumnya terdiri dari atas penerangan untuk reklame, kipas angin, penyejuk udara dan alat-alat listrik lainnya yang diperlukan untuk restoran. Beban hotel juga diklasifikasikan sebagai beban komersial (bisnis) begitu juga perkantoran. Beban ini secara drastis naik di siang hari untuk beban perkantoran dan pertokoan menurun di waktu sore hari.

3. Beban industri dibedakan dalam skala kecil dan skala besar. Untuk skala kecil banyak beroperasi pada siang hari sedangkan industri besar sekarang ini banyak yang beroperasi sampai 24 jam.

4. Beban Fasilitas Umum.

Berdasarkan karakteristik teknis menyebabkan posisi pembangkit dalam mensuplai beban sistem berbeda, yang umumnya dikelompokkan menjadi pembangkit pemikul beban dasar (base load) dan pemikul beban puncak (peak load). 
172 Makmur Saini, A.M. Shiddiq Yunus, Firdaus. Studi Estimasi Beban Puncak Hari Libur Nasional Sistem Interkoneksi Sulselbar Menggunakan Jaringan Syaraf Tiruan Propagasi Balik

Beban dasar (baseload) adalah beban mnimum pada sistem tenaga listrik selama periode waktu tertentu. Sedangkan beban puncak (peak load) adalah beban maksimum pada sistem tenaga listrik selama periode waktu tertentu yang harus dipenuhi oleh PLN agar tidak terjadi pemadaman.

\section{C) Peramalan}

\section{Pengertian Peramalan}

peramalan beban merupakan suatu cara untuk memperkirakan berapa besar kebutuhan beban di masa mendatang. Ramalan bisa bersifat kualitatif maupun kuantitatif. Ramalan kualitatif tidak berbentuk angka, misalnya besok akan turun hujan, hasil penjualan akan meningkat, dan sebagainya. Sedangkan ramalan kuantitatif dinyatakan dalam bentuk angka atau bilangan [3].

Menurut jangka waktunya, peramalan di bagi menjadi 3 periode, sesuai dengan materi yang diramalkannya. Dalam peramalan beban listrik, periode peramalan dibagi menjadi 3, yaitu ;

a. Peramalan Jangka Panjang (Long-term Forecasting)

Merupakan peramalan yang memperkirakan keadaan dalam waktu beberapa tahun ke depan. Tujuannya adalah untuk dapat mempersiapkan ketersediaan unit pembangkutan, sistem transmisi, serta distribusi.

b. Peramalan Jangka Menengah (Mid-Term Forecasting)

Merupakan peramalan dalam jangka waktu bulanan atau mingguan. Tujuannya untuk mempersiapkan jadwal persiapan dan operasional sisi pembangkit.

c. Peramalan Jangka Pendek (Short-Term Forecasting)

Merupakan peramalan beban harian hingga setiap jam. Besarnya beban untuk setiap jam ditentukan dengan memperhatikan trend beban di waktu lalu dengan memperhatikan berbagai informasi yang dapat mempengaruhi besarnya beban sistem.

\section{Prinsip Peramalan}

Peramalan memiliki empat karakteristik atau prinsip. Dengan memahami prinsip-prinsip membantu agar mendapatkan peramalan yang lebih efektif. Berikut empat prinsip permalan tersebut.

a. Peramalan biasanya salah. Dalam kegiatan peramalan, kesalahan adalah hal yang wajar karena masa depan yang tidak diketahui oleh siapa pun.

b. Setiap peramalan seharusnya menyertakan estimasi kesalahan (error). Perbedaan antara nilai yang diprediksikan dengan nilai aktualnya akan menghasilkan besar kesalahan sehingga setiap peramalan seharusnya juga menyertakan estimasi kesalahan yang dapat diukur sebagai tingkat kepercayaan, dapat berupa presentase (plus atau minus) dari peramalan sebagai rentang nilai minimum (batas bawah) dan maksimum (batas atas).

c. Peramalan akan lebih akurat untuk kelompok atau grup. Perilaku dari individual dalam sebuah grup tersebut berada dalam keadaan stabil. Sebagai contoh, meramalkan secara akurat seorang murid dalam satu kelas lebih sulit daripada meramalkan untuk rata-rata keseluruhan kelas. Dengan kata lain, peramalan lebih akurat untuk dilakukan pada kelompok atau grup dibandingkan individual.

Peramalan lebih akurat untuk jangka waktu yang lebih dekat. Kebanyakan orang lebih yakin untuk meramalkan apa yang akan mereka lakukan minggu depan dibanding meramalkan apa yangakan mereka lakukan tahun depan. Karena masa depan lebih jauh memiliki nilai ketidakpastian yang tinggi dibandingkan masa depan dalam jangka waktu pendek. 


\section{D) Metode Koefisien}

Metode ini dipakai untuk meramalkan beban dari suatu sistem tenaga listrik. Beban untuk setiap jam diberi koefisien yang menggambarkan besarnya beban pada jam tersebut dalam perbandingannya terhadap beban puncak [4].

Perbedaan metode koefisien beban dengan jaringan syaraf tiruan propagasi balik yaitu pada metode koefisien beban merupakan beban untuk setiap jamnya diberikan koefisien yang menggambarkan besarnya beban pada jam tersebut. Sedangkan untuk metode jaringan syaraf tiruan propagasi balik meminimalkan error pada output yang dihasilkan oleh jaringan. Propagasi balik melatih jaringan untuk mendapatkan keseimbangan antara kemampuan jaringan untuk menjadi pola yang digunakan selama pelatihan serta kemampuan jaringan untuk memberikan respon yang benar terhadap pola masukan yang serupa (tapi tidak sama) dengan pola yang dipakai selama pelatihan.

\section{E) Jaringan Syaraf Tiruan}

Jaringan syaraf tiruan (JST) adalah sistem pemroses informasi yang memiliki karakteristik mirip dengan jaringan syaraf biologi [5].

Beberapa aplikasi jaringan syaraf tiruan adalah sebagai berikut:

a. Pengenalan pola (Pattern Recognition)

Jaringan syaraf tiruan dapat dipakai untuk mengenali pola (misal huruf, angka, suara atau tanda tangan) yang sudah sedikit berubah. Hal ini mirip dengan otak manusia yang masih mampu mengenali orang yang sudah beberapa waktu tidak dijumpainya (mungkin wajah/bentuk tubuhnya sudah sedikit berubah.

b. Signal Processing

Jaringan syaraf tiruan (model ADALINE) dapat dipakai untuk menekan noise dalam saluran telepon.

c. Peramalan

Jaringan syaraf tiruan juga dapat dipakai untuk meramalkan apa yang akan terjadi di masa yang akan datang berdasarkan pola kejadian yang ada di masa lampau. Ini dapat dilakukan mengingat kemampuan jaringan syaraf tiruan untuk mengingat dan membuat generalisasi dari apa yang sudah ada sebelumnya.

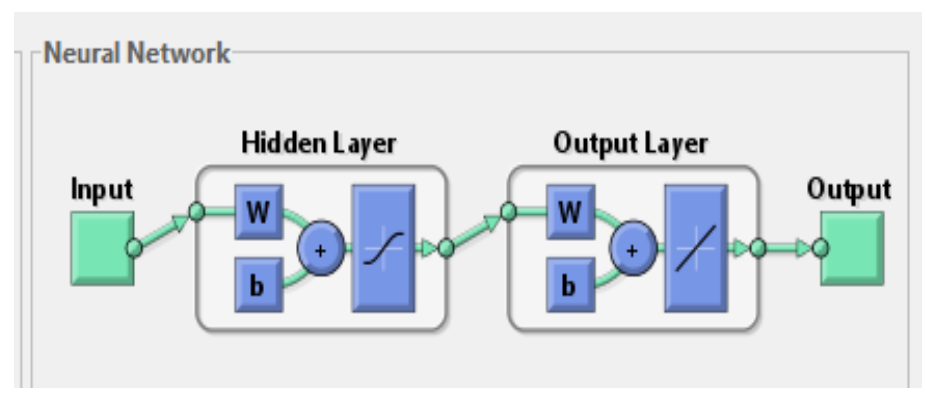

Gambar 1. Komponen Jaringan Syaraf Tiruan

\section{METODE PENELITIAN}

\section{A) Tempat dan Waktu Penelitian}

Proses kegiatan penelitian ini dilakukan di PT. PLN (Persero) Unit Pengatur Beban Sistem Sulselbar dimulai pada Bulan Agustus 2017 sampai Oktober 2017.

\section{B). Prosedur Penelitian}

Langkah-langkah prosedur penelitian dapat dilihat pada Gambar 1 Diagram Alir Prosedur Penelitian berikut: 
174 Makmur Saini, A.M. Shiddiq Yunus, Firdaus. Studi Estimasi Beban Puncak Hari Libur Nasional Sistem Interkoneksi Sulselbar Menggunakan Jaringan Syaraf Tiruan Propagasi Balik

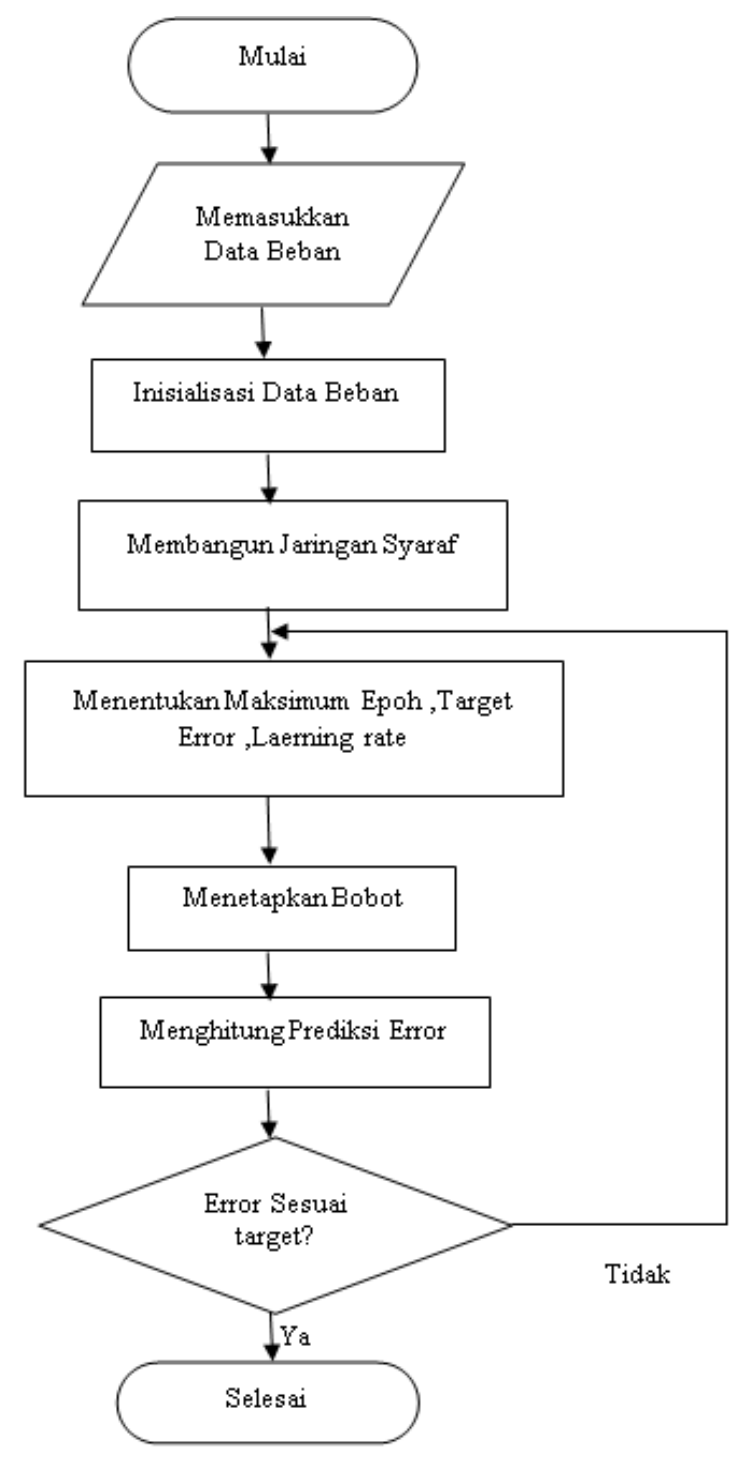

Gambar 2. Diagram Alir Peramalan Beban Metode Propagasi Balik

\section{HASIL DAN PEMBAHASAN}

\section{A. Hasil Penelitian}

1. Persiapan Data

Daya beban listrik yang digunakan sebagai data dalam pengolahan data penelitian ini merupakan data daya beban listrik yang terdapat pada sistem interkoneksi SULSELBAR yang dinyatakan dalam satuan Mega Watt (MW). Data historis yang digunakan sebagai data acuan untuk pengolahan data dalam penelitian ini merupakan data beban puncak listrik hari libur nasional tahun 2010 sampai dengan tahun 2016. Pengambilan sampel data dalam rentang waktu tersebut cukup untuk melihat dan mengetahui karakteristik serta trend yang terbentuk berdasarkan hasil perencanaan.

2. Pengolahan Data

Pada pengolahan data ini, proses perencanaan beban dimulai dengan pelatihan menggunakan metode propagasi balik (backpropagation) untuk pengenalan pola beban puncak listrik hari libur nasional dan diharapkan memperoleh hasil yang akurat yang mendekati dengan data target pelatihan. 
Apabila nilai Regression bernilai 1 atau mendekati 1 maka selanjutnya melakukan simulasi dengan memakai data simulasi tahun 2015, setelah melakukan simulasi memakai data tahun 2015 maka selanjutnya menghitung error dari pemodelan tadi. Apabila pemodelan belum mendapatkan error yang diinginkan maka dilakukan trial and error sampai medapatkan error yang diinginkan.

Setelah mendapatkan error yang diinginkan maka selanjutnya memakai data tahun 2016 untuk melakukan estimasi beban puncak hari libur nasional tahun 2017. Adapun software yang digunakan dalam simulasi ini adalah Matlab [6], [7].

a. Pendefinisian Input

Data yang telah diperoleh untuk merencanakan beban yaitu data beban puncak hari libur nasional tahun 2010 sampai dengan tahun 2015 digunakan sebagai input data pada proses jaringan syaraf tiruan propagasi balik (backpropagation). Data input terbagi menjadi dua bagian yaitu data pelatihan dan data simulasi. Data pelatihan yang digunakan pada penelitian ini adalah data beban puncak hari libur nasional tahun 2010 sampai dengan tahun 2014 dan data simulasi yang digunakan pada penelitian ini adalah data beban puncak hari libur nasional tahun 2015.

Tabel 1. Data Pelatihan Beban Puncak Hari Libur Nasional.

\begin{tabular}{|c|c|c|c|c|c|c|}
\hline \multirow{2}{*}{ NO } & \multirow{2}{*}{ HARI LIBUR NASIONAL } & \multicolumn{5}{|c|}{ TAHUN / BEBAN PUNCAK (MW) } \\
\cline { 3 - 7 } & & 2010 & 2011 & 2012 & 2013 & 2014 \\
\hline 1 & Tahun Baru Masehi & 481.24 & 476.7 & 546.97 & 602.65 & 631.3 \\
\hline 2 & Tahun Baru Imlek & 502.29 & 553.63 & 584 & 670.72 & 703.3 \\
\hline 3 & Hari Raya Nyepi & 535.77 & 551.37 & 608.87 & 678.49 & 799.9 \\
\hline 4 & Wafat Yesus Kristus & 521.4 & 559.91 & 583.12 & 719.4 & 801 \\
\hline 5 & Isra' Mi'raj Nabi Muhammad & 492.49 & 560.06 & 596.83 & 699.43 & 770.3 \\
\hline 6 & SAW & 539.05 & 520.96 & 619.9 & 753.09 & 829.4 \\
\hline 7 & Hari Buruh Internasional & 518.9 & 599.92 & 605.16 & 691.81 & 745.5 \\
\hline 8 & Kenaikan Yesus Kristus & 518.43 & 576.92 & 617.15 & 734.73 & 776.6 \\
\hline 9 & Hari Lahir Pancasila & 530.99 & 591.54 & 647.09 & 724.36 & 765.5 \\
\hline 10 & Idul Fitri 1 & 429.86 & 545.06 & 550.83 & 626.06 & 636.2 \\
\hline 11 & Idul Fitri 2 & 448.07 & 514.71 & 567.59 & 617.02 & 662.7 \\
\hline 12 & Hari Kemerdekaan RI & 531.3 & 572.52 & 613.72 & 726.33 & 735.2 \\
\hline 13 & Idul Adha & 487.81 & 554.45 & 621.12 & 700.33 & 721 \\
\hline 14 & Tahun Baru Hijriyah & 554.48 & 592.95 & 680.69 & 783.51 & 781.3 \\
\hline 15 & Maulid Nabi Muhammad & 507.03 & 545.75 & 602.74 & 667.77 & 717.5 \\
\hline 16 & SAW & 490.04 & 576.41 & 663.05 & 652.17 & 860.8 \\
\hline
\end{tabular}


176 Makmur Saini, A.M. Shiddiq Yunus, Firdaus. Studi Estimasi Beban Puncak Hari Libur Nasional Sistem Interkoneksi Sulselbar Menggunakan Jaringan Syaraf Tiruan Propagasi Balik

Tabel 2. Data Simulasi Beban Puncak Hari Libur Nasional Tahun 2015.

\begin{tabular}{|c|c|c|c|c|}
\hline NO & HARI LIBUR NASIONAL & BEBAN & \multirow{2}{*}{ HARI } & TANGGAL \\
& & PUNCAK & & \\
\hline 1 & Tahun Baru Masehi & 713.1 & Kamis & 1 Januari \\
\hline 2 & Tahun Baru Imlek & 805.2 & Kamis & 19 Februari \\
\hline 3 & Hari Raya Nyepi & 817 & Sabtu & 21 Maret \\
\hline 4 & Wafat Yesus Kristus & 808.8 & Jumat & 3 April \\
\hline 5 & Isra' Mi'raj Nabi Muhammad SAW & 806.2 & Sabtu & 16 Mei \\
\hline 6 & Hari Buruh Internasional & 799 & Jumat & 1 Mei \\
\hline 7 & Hari Raya Waisak & 785.4 & Selasa & 2 Juni \\
\hline 8 & Kenaikan Yesus Kristus & 840.3 & Kamis & 14 Mei \\
\hline 9 & Hari Lahir Pancasila & 826.8 & Senin & 1 Juni \\
\hline 10 & Idul Fitri 1 & 701.3 & Jumat & 17 Juli \\
\hline 11 & Idul Fitri 2 & 720.5 & Sabtu & 18 Juli \\
\hline 12 & Hari Kemerdekaan RI & 799.1 & Senin & 17 Agustus \\
\hline 13 & Idul Adha & 755.2 & Kamis & 24 September \\
\hline 14 & Tahun Baru Hijriyah & 858 & Rabu & 14 Oktober \\
\hline 15 & Maulid Nabi Muhammad SAW & 649.3 & Sabtu & 3 Januari \\
\hline 16 & Hari Raya Natal & 741.2 & Jumat & 25 Desember \\
\hline
\end{tabular}

Tabel 3. Data Target Beban Puncak Hari Libur Nasional Tahun 2016

\begin{tabular}{|c|c|c|c|c|}
\hline NO & HARI LIBUR NASIONAL 2016 & $\begin{array}{c}\text { BEBAN } \\
\text { PUNCAK }\end{array}$ & HARI & TANGGAL \\
\hline 1 & Tahun Baru Masehi & 808.10 & Jumat & 1 Januari \\
\hline 2 & Tahun Baru Imlek & 929.40 & Senin & 8 Februari \\
\hline 3 & Hari Raya Nyepi & 916.90 & Rabu & 9 Maret \\
\hline 4 & Wafat Yesus Kristus & 880.40 & Jumat & 25 Maret \\
\hline 5 & Isra' Mi'raj Nabi Muhammad SAW & 917.60 & Jumat & 6 Mei \\
\hline 6 & Hari Buruh Internasional & 962.20 & Minggu & 1 Mei \\
\hline 7 & Hari Raya Waisak & 967.70 & Minggu & 22 Mei \\
\hline 8 & Kenaikan Yesus Kristus & 884.60 & Kamis & 5 Mei \\
\hline 9 & Hari Lahir Pancasila & 934.40 & Rabu & 1 Juni \\
\hline 10 & Idul Fitri 1 & 752.10 & Rabu & 6 Juli \\
\hline 11 & Idul Fitri 2 & 776.60 & Kamis & 7 Juli \\
\hline 12 & Hari Kemerdekaan RI & 943.50 & Rabu & 17 Agustus \\
\hline 13 & Idul Adha & 913.10 & Senin & September \\
\hline 14 & Tahun Baru Hijriyah & 993.40 & Minggu & 2 Oktober \\
\hline 15 & Maulid Nabi Muhammad SAW & 912.30 & Senin & 12 Desember \\
\hline 16 & Hari Raya Natal & 923.80 & Minggu & 25 Desember \\
\hline
\end{tabular}




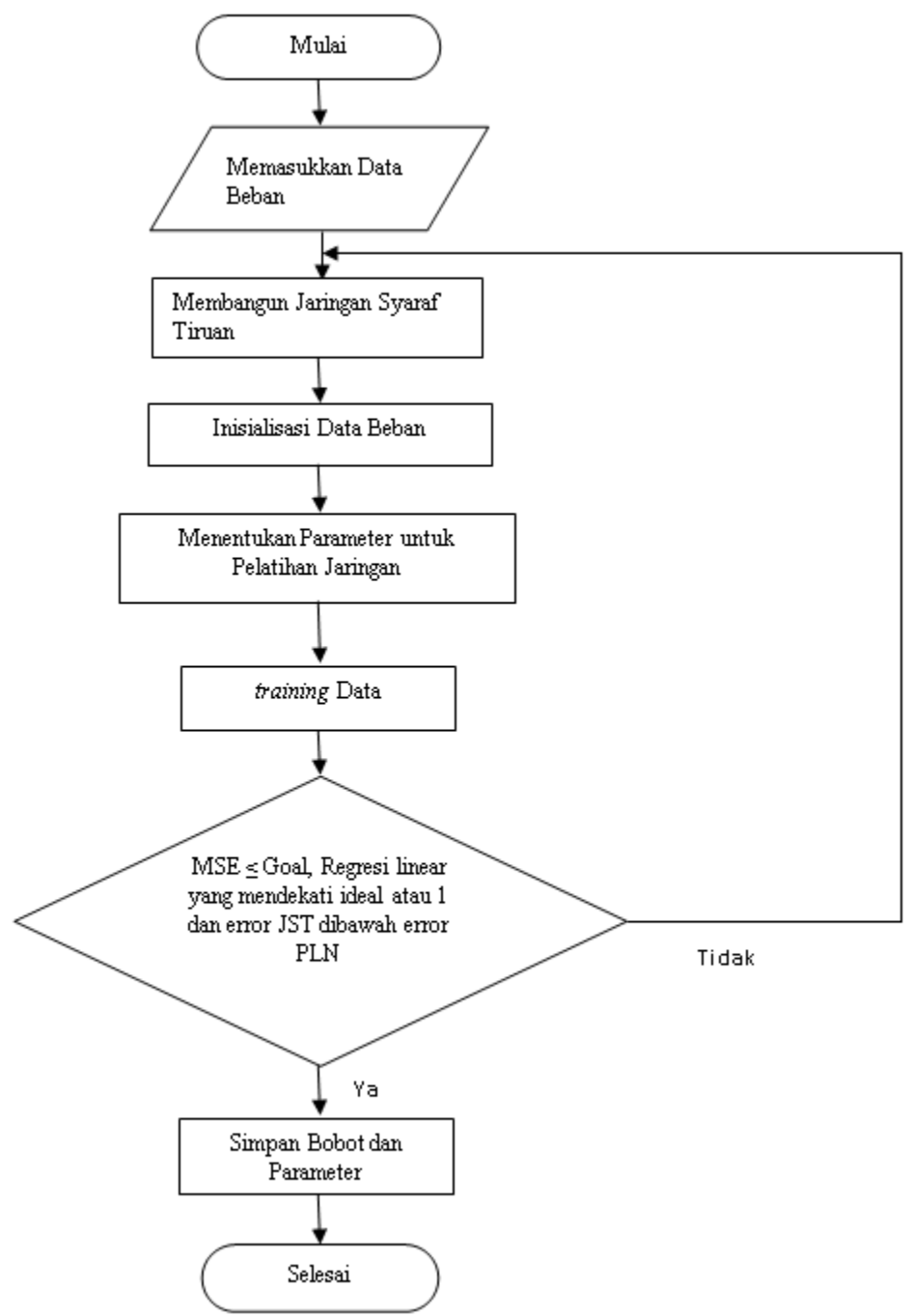

Gambar 3. Flowchart Proses Pelatihan pada Toolbox Neural Network Matlab
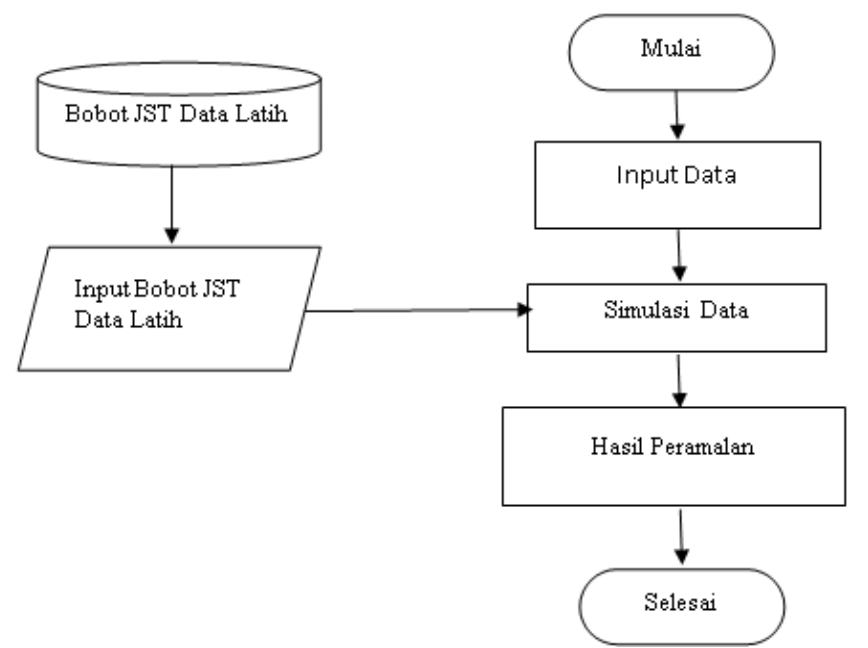

Gambar 4. Flowchart Proses Simulasi pada Toolbox Neural Network Matlab 
178 Makmur Saini, A.M. Shiddiq Yunus, Firdaus. Studi Estimasi Beban Puncak Hari Libur Nasional Sistem Interkoneksi Sulselbar Menggunakan Jaringan Syaraf Tiruan Propagasi Balik

\section{B. PEMBAHASAN}

Pada pembahasan ini kami akan membahas perbandingan error dari hasil trial and error dan hasil peramalan. Pertama dari hasil trial and error untuk mendapatkan paramater yang bagus untuk melakukan permalan.

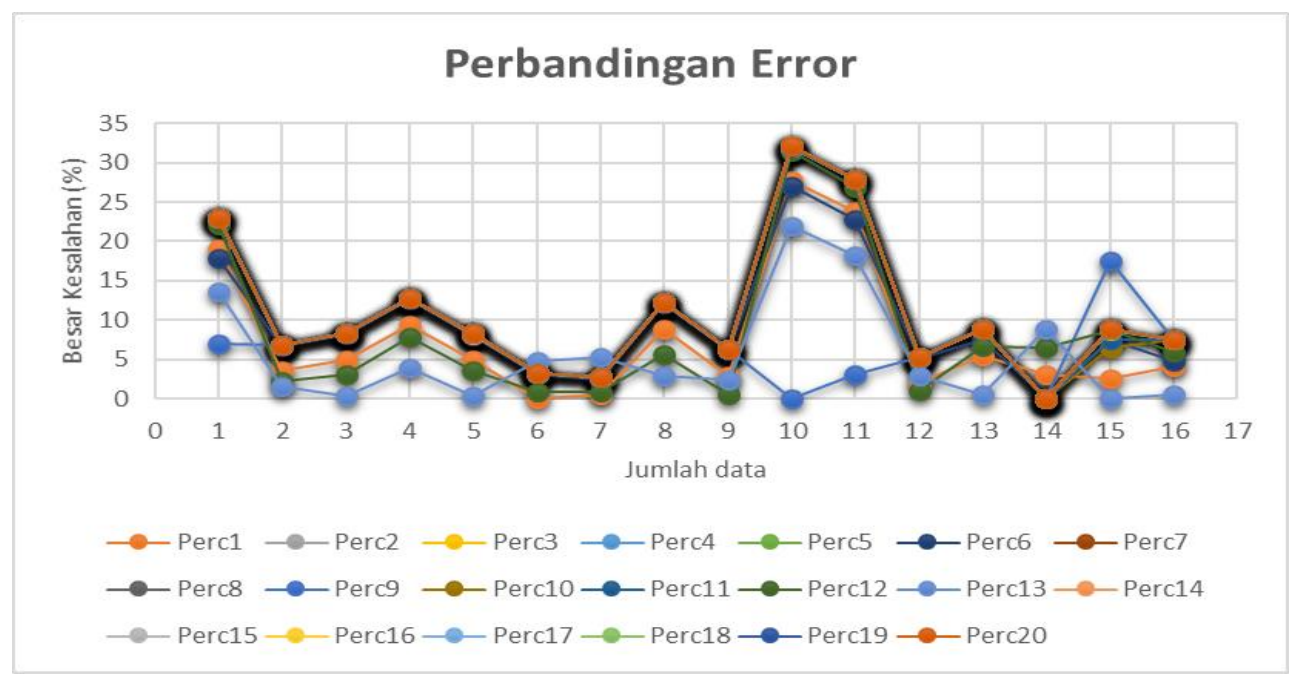

(a)

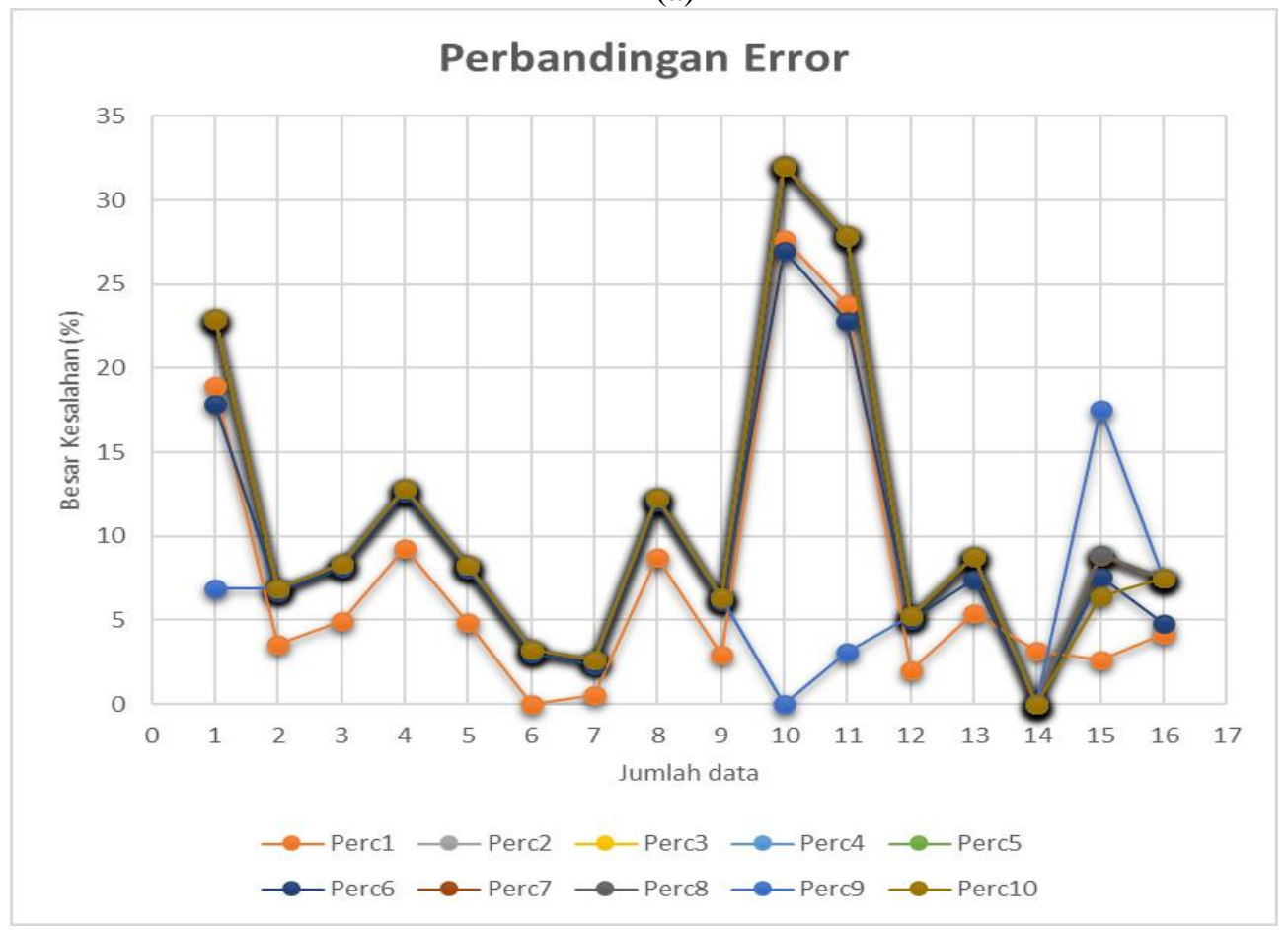

(b) 


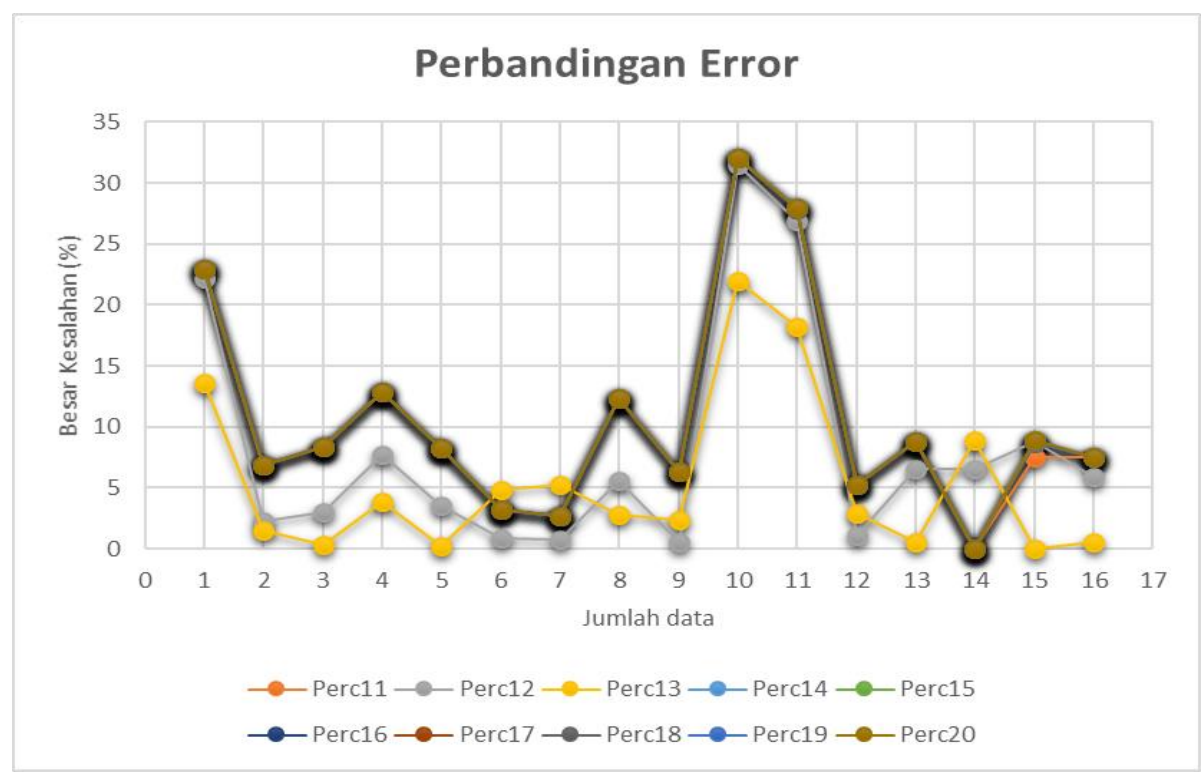

(c)

Gambar 5. (a) perbandingan error percobaan 1 - percobaan 20

(b) perbandingan error percobaan 1 - percobaan 10

(c) perbandingan error percobaan 11- percobaan 20

Pada gambar di atas terlihat bahwa pada percobaan 13 merupakan percobaan ada 11 hari libur nasional yang mempunyai error di bawah 5\% yaitu Tahun Baru Imlek, Hari Raya Nyepi, Wafat Yesus Kristus, Isra' Mi'raj Nabi Muhammad SAW, Hari Buruh Internasional, Kenaikan Yesus Kristus, Hari Lahir Pancasila, Hari Kemerdekaan RI, Idul Adha, Maulid Nabi Muhammad SAW, Hari Raya Natal, dan error terkecilnya yaitu $0,0216 \%$. Percobaan 3 Cuma ada 3 hari libur nasional yang mempunyai error di bawah $5 \%$ yaitu Hari Buruh Internasional, Hari Raya Waisak, Tahun Baru Hijriyah dengan error yang paling besar yaitu $32,083 \%$. Sehingga percobaan 13 yang dipakai dalam meramalkan.

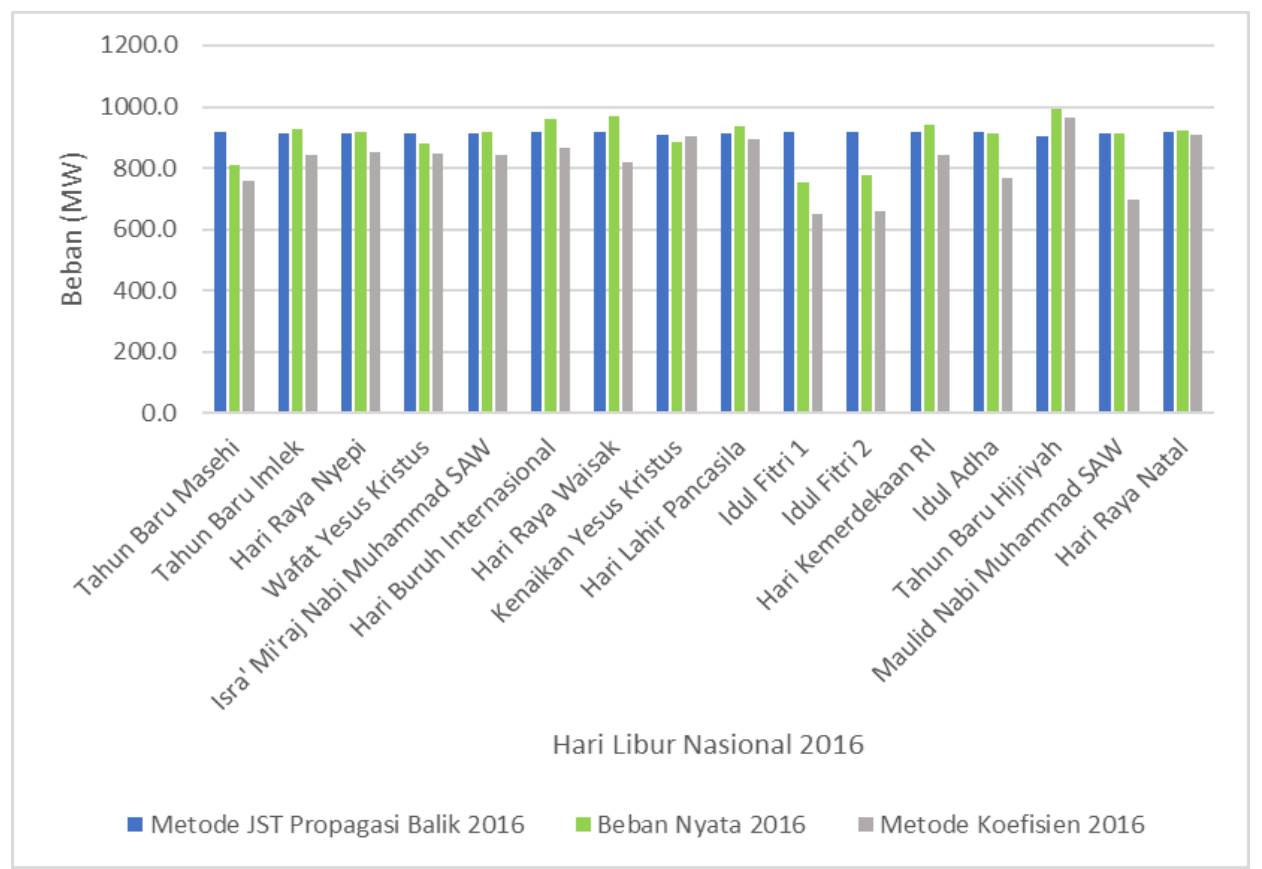

Gambar 6. Perbandingan Metode Peramalan dengan Beban Nyata Tahun 2016 
Pada Gambar 6 terlihat bahwa grafik batang berwarna biru dan hijau lebih banyak yang berhimpitan atau hampir sama tinggi yang berarti nilai atau peramalan beban metode Jaringan Syaraf Tiruan Propgasi Balik dengan beban nyata tidak jauh berbeda nilainya. Sedangkan grafik berwarna hijau dengan abu-abu rata-rata grafiknya tidak berhimpitan atau tingginya terlalu beda jauh yang artinya nilai atau beban metode Jaringan Syaraf Tiruan Propagasi Balik dengan beban nyata berbeda jauh. Kemudian, setelah melakukan trial and error dan mendapatkan parameter serta bobot yang dapat dilihat pada lampiran 21 maka akan dilakukan peramalan untuk meramalkan beban listrik hari libur nasional yang dimana langkah-langkahnya telah dijelaskan sebelumnya. Adapun yang kedua akan dibahas yaitu hasil peramalan yang dimana kita dapat melihat grafik peramalan beban hari libur nasional tahun 2017 gambar 7 di bawah ini.

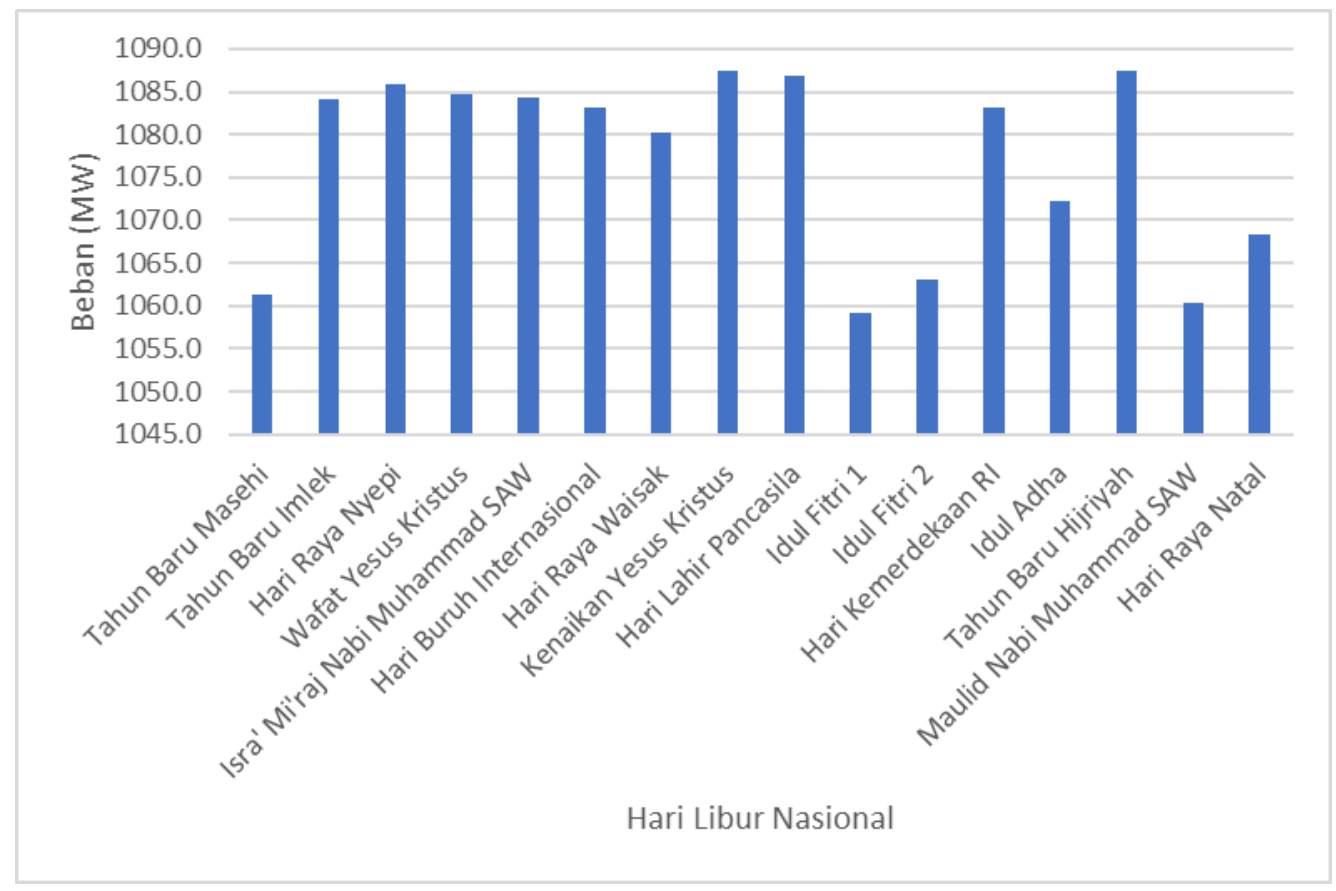

Gambar 7. Peramalan beban puncak hari libur nasional tahun 2017

Pada gambar 7 terlihat bahwa beban tertinggi 1087,512 MW yaitu pada hari kenaikan Yesus Kristus dimana hari itu bertepatan dengan hari kamis tanggal 25 Mei dimana pada hari jumatnya pegawai kantoran tetap masuk kantor sehingga beban puncak pada hari itu tidak jauh beda dengan hari-hari biasa karena libur Cuma satu hari, sedangkan beban terendah 1059,232 MW pada hari Idul Fitri 1 bertepatan dengan hari minggu tanggal 25 Juni dan rata-rata kantor libur ditambah Idul Fitri dibarengi dengan cuti bersama yang hampir 1 minggu sehingga banyak pegawai kantoran yang pulang kampung untuk merayakan hari raya idul fitri bersama keluarga sehingga beban pada hari itu rendah.

\section{KESIMPULAN}

1. Hasil peramalan beban puncak hari libur nasional 2017 beban terkecil pada tanggal 25 Juni 2017 bertepatan dengan hari raya idul fitri yaitu 1059,2 MW dan beban terbesar pada tanggal 25 Mei 2017 yaitu 1087,5 MW.

2. Hasil perbandingan error antara metode koefisien dan metode Jaringan Syaraf Tiruan Backpropagation menunjukkan bahwa metode Jaringan Syaraf Tiruan Backpropagation memiliki error di bawah $5 \%$ lebih banyak daripada metode koefisien yang berarti akurasi perencanaan beban dengan metode jaringan syaraf tiruan backpropagation lebih akurat daripada metode koefisien beban.. 


\section{DAFTAR PUSTAKA}

[1] Dwiantoro, Bagus. 2012. Peramalan Beban Listrik Jangka Pendek Berdasarkan Data Historis menggunakan Metode Generalized Autoregressive Conditional Heteroskedasticity (GARCH). Skripsi. Universitas Indonesia.

[2] Suswanto, Daman. 2009. Sistem Distribusi Tenaga Listrik. Padang:Universitas Negeri Padang.

[3] Binoto, Maju dkk. 2012. Peramalan Beban Listrik Jangka Pendek Menggunakan Jaringan Syaraf Tiruan di Kabupaten Karanganyar - Jawa Tengah. Jurnal Eltek.

[4] Khair, Aulia. 2011. Peramalan Beban Listrik Jangka Pendek Menggunakan Kombinasi Metode Autoregressive Integrated Moving Average (ARIMA) dengan Regresi Linear antara Suhu dan Daya Listrik. Skripsi. Universitas Indonesia.

[5] Anike, Marleni. 2012. Pengembangan Sistem Jaringan Syaraf Tiruan Dalam Memprediksi Jumlah Dokter Keluarga Menggunakan Backpropagation. Tesis. Universitas Atma Jaya Jogyakarta.

[6] Kusumadewi, Sri. 2004. Membangun Jaringan Syaraf Tiruan Menggunakan Matlab dan Excel Link. Yogyakarta: GRAHA ILMU.

[7] Siang, J.J. 2009. Jaringan Syaraf Tiruan dan Pemrogramannya Menggunakan MATLAB. Yogyakarta: ANDI. 